\title{
Effectiveness of the Regional School Operational Assistance Program for Madrasas in Bekasi Municipal Government in the Decentralization Era: A Case Study of Madrasah Ibtidaiyah Negeri Bekasi Municipality and Madrasah Tsanawiyah Negeri 1 Bekasi Municipality
}

\author{
Lulu Nurul Fitri ${ }^{1, *}$ Irfan Ridwan Maksum²
}

\author{
${ }^{1}$ Faculty of Administrative Science, Department of Public Administration, University of Indonesia \\ ${ }^{2}$ Faculty of Administrative Science, Department of Public Administration, University of Indonesia \\ *Corresponding author. Email: lulunf23@gmail.com
}

\begin{abstract}
Recently, Indonesia prioritized education for everyone to reach the United Nation's sustainable development goals (SDGs). Generally, central and regional governments have the authority to implement education to achieve fair and inclusive education nationwide. To enhance the overall quality of education, regional governments are implementing the Regional School Operational Assistance (Bantuan Operasional Sekolah Daerah, BOSDA) program. This program is a school operational assistance program that provides middle and elementary schools with funds from the regional budget for operational expenses. Hence, Bekasi municipal government decided to make BOSDA available to both public schools and madrasas. Local governments rarely support madrasas through BOSDA because madrasas are considered the concern of the central government. This study uses a postpositivist descriptive approach to analyze the effectiveness of this BOSDA program in education in madrasas in the Bekasi Municipality. The results of this study showed that the BOSDA program implemented in Madrasah Ibtidaiyah Negeri Bekasi Municipality and Madrasah Tsanawiyah Negeri 1 Bekasi Municipality is fairly effective in helping madrasas develop their infrastructure and human resources. This study is expected to encourage other regions to take part in developing madrasas, thereby contributing to enhancing the overall access to education and achieving comprehensive education equality throughout Indonesia.
\end{abstract}

Keywords: BOSDA, Madrasa, Local Government, Central Government, Decentralization, Education

\section{INTRODUCTION}

Following the reform that took place in the unitary state of the Republic of Indonesia, Indonesia began reforming its regional administrative system in 1999 to increase regional autonomy. This reform began with the passing of Law 22/1999, which was later amended as Law 32/2004 and again as the current law, Law 23/2014 on Regional Government. This regional autonomy law gives all regions full authority to manage their own region. This is apparent in the distribution of authority, which is regulated into various government affairs. Government affairs are classified as follows: (i) absolute government affairs, which are matters that are fully reserved to the central government; (ii) concurrent government affairs, which are government matters shared between the central and local governments, namely, provinces and regencies/municipalities; and (ii) general government affairs, in which the central government is also given authority.

Education is an obligatory affair shared between central and local governments. Although education has been transferred to all regions, not all types of education are decentralized, such as Islamic education, or madrasas. Madrasas are formal educational institutions managed by the Ministry of Religious Affairs; in other words, madrasas are centrally managed. The Ministry of Religious Affairs (Kementerian Agama, Kemenag) directly develops and manages all madrasas throughout Indonesia. A long time ago, madrasas emerged, grew, and developed in Indonesia alongside the arrival and development of Islam. These madrasas developed into different levels and types, alongside the development of the Indonesian nation, through the Sultanate period, the colonial period, and the period of independence (Fadjar, 1998). Madrasas generally contribute to the national character by cultivating religious values through 
education, as well as passing down general knowledge, and they also expand education in Indonesia and help in achieving compulsory education and increasing the school participation rate nationwide (Alawiyah, 2014).

The significant contribution of madrasas, nevertheless, stands in stark contrast to their generally limited resources. Madrasas often encounter operational problems, such as insufficient teaching personnel, lack of facilities and equipment, and low public participation. These problems are the result of the limited funds allocated to madrasas; the central government's education budget for madrasas is always much smaller than that for public schools (Murtadho, 2012). Moreover, many local governments feel that madrasas are the responsibility of the central government, which in this case is the Ministry of Religious Affairs. As a result, many local governments do not support the development of madrasas. System records do not reflect a discrepancy between madrasas and public schools. According to Law 22/2003 on National Education System (UU Sisdiknas), the position and status of madrasas are the same as those of other public schools. Madrasah Ibtidaiyah (MI) is regarded as equivalent to elementary school (Sekolah Dasar, SD), Madrasah Tsanawiyah (MTs) is equivalent to middle school (Sekolah Menengah Pertama, SMP), and Madrasah Aliyah (MA) is equivalent to high school (Sekolah Menengah Atas, SMA). Additionally, in UU Sisdiknas, it is stipulated that central and local governments are responsible for funding the education budget; in other words, the management of madrasas is not the sole responsibility of the Ministry of Religious Affairs; there should also be involvement from the local government. This serves as the basis for Bekasi Municipal Government's decision to support the development of madrasas within their locality. Unlike other local governments in Indonesia, the Bekasi Municipal Government assists in the management of madrasas by providing an assistance fund from Bekasi Municipality Regional Budget, the Regional School Operational Assistance (Bantuan Operasional Sekolah Daerah, BOSDA) program. The aim of this program is to exempt students at public SD/MI and SMP/MTs schools from paying school operational expenses and to lighten these expenses for students at private SD/MI and SMP/MTs schools.

The amount of BOSDA funds provided to students differs. For assistance at Madrasah Tsanawiyah Negeri (MTsN, public MTs), each student receives IDR 90,000; for assistance at Madrasah Tsanawiyah Swasta (MTsS, private MTs), each student receives IDR 15,000; for Madrasah Ibtidaiyah Negeri (MIN, public MI), each student receives IDR 28,000; and for Madrasah Ibtidaiyah Swasta (MIS, private MI), each student receives IDR 10,000. Given the number of students, the BOSDA fund that madrasas receive is used as a subsidy for the students and can later be used to fund a madrasa's operational activities. This regulation is stipulated in Bekasi Mayoral Regulation No. 49.A/2012 on the Management of Education Implementation of Operational Expenses in Private Schools, Public and Private Madrasas, and Salafiyah with Budget Derived from the Bekasi Municipality Regional Budget. This regulation explains that the cost of implementing regional school operational education assistance for madrasas is specified in Bekasi Municipality's Private School Operational Assistance (private BOSDA). Article 2 of the regulation states that the intent and purpose for providing BOSDA is to alleviate the burden of operational expenses of local resident students and to assist with the school operational expenses. Articles 1 and 2 explain that BOSDA shall be used to fund operational activities that consist of personnel expenditure and services and goods expenditure. As previously discussed, the amount of BOSDA fund allocated to each madrasa is adjusted according to the number of students. According to data from the Ministry of Religious Affairs (Kemenag) on 2018, Madrasah Tsanawiyah Negeri 1 (MTsN 1) Bekasi Municipality has the largest number of students (i.e., 1,225 in total). In addition, MIN Bekasi Municipality is the only state with 450 students in MI. Hence, one can ascertain that when the number of students is large, madrasas receive a large amount of BOSDA fund. As a result, they should have a greater ability to support their personnel and improve their infrastructure (Hidayat, 2014). The following question is, thus, posed in this study: How effective is Bekasi Municipal Government's BOSDA program for madrasas in Bekasi in the decentralization era? The aim of this study is to encourage other regions to take part in developing madrasas, thereby contributing to enhancing access to education and achieving comprehensive education equality throughout Indonesia.

\section{RESEARCH METHODS}

This study uses a postpositivist approach, which involves collecting data that either support or oppose a theory to improve that theory before additional trials are conducted on the basis of such theory (Cresswell, 2014). Generally, a theory is created out of numerous concepts that indicate correlations between one another. In postpositivist research, theories are not a measuring tool or a test for a hypothesis. Rather, they are used as guidance to focus and narrow the research. On the basis of this objective, this study can be categorized as descriptive research. Descriptive research generally tries to provide an answer to "what" something is. Aside from thoroughly describing the characteristics of a particular phenomenon or subject, descriptive research also focuses on "how" something is by acquiring and conveying facts in a clear, meticulous, and complete manner (Silalahi, 2015). This study is considered descriptive research because it aims to describe in detail 
the effectiveness of Bekasi Municipal Government's BOSDA program for madrasas in the Bekasi Municipality. The research data included both primary and secondary data. Primary data were collected from in-depth interviews with eight informants:

- The Coordinator of SMP/MTs-level BOSDA of Bekasi Municipal Education Office, Endah Puji Astuti S.Sos

- $\quad$ The Coordinator of SD/MI level-BOSDA of Bekasi Municipal Education Office, Ependi

- The Head of MTsN 1 Bekasi Municipality, Dr. H. Bukhori, M.Pdi

- The Treasurer of MTsN 1 Bekasi Municipality, Siti Salimah

- The Head of MIN Bekasi Municipality, H. Genon, S.Ag

- The Treasurer of MIN Bekasi Municipality, Halimah, S.Ag

- Third Party, Tengku Imam Kobul Moh. Yahya S., as Education Observer

Secondary data were collected from literature studies of books, newspapers, scientific journals, prior study results, and other relevant documents. Descriptive analysis was used to explore and describe all the data. This study was conducted in MTsN 1 Bekasi Municipality, MIN Bekasi Municipality, and Bekasi Municipal Education Office.

\section{RESULTS}

Subagyo (2000) defined effectiveness as alignment between output and determined goals (Subagyo, 2000). Effectiveness is a condition that aligns with what has been planned, and it is a condition that occurs because it is intended to occur. If an individual were to commit a certain action with a particular intent, and it is indeed intended, then that individual's work can be considered effective when it generates impact or achieves what was intended (Gie, 1997). Furthermore, when effectiveness is associated with a program, then that program's effectiveness refers to the alignment between the objective and the result obtained within that program. If this program functioned in line with the planned objective, then it may be considered an effective program. Effectiveness is generally viewed as a level that reaches operational and operative goals. Assessment of program alignment levels is one of the means used to measure program effectiveness. Accordingly, to understand the achievement of a goal within a program, standards of effectiveness are required to measure the success of that program. According to Dale (2014), effectiveness can be assessed by examining the input, process, and output. Assessments at the process and input level are conducted to examine how inputs and program implementation are received by beneficiaries, whereas assessments at the output level are carried out to assess targets that are to be achieved. The derivative of this concept will be combined with other effectiveness assessment indicators (Dale, 2004). In line with Dale, Heryendi (Budiani, 2007) measured program effectiveness in his research entitled "Efektivitas Program Usaha Peningkatan Pendapatan Keluarga Sejahtera (UPPKS) Di Kecamatan Denpasar Barat" (Effectiveness of the Prosperous Family Income Improvement Efforts (UPPKS) Program in West Denpasar District) using the following dimensions:

- Input in program implementation covers employees' information dissemination, assistance in line with needs, punctuality of assistance, amount of assistance in line with agreement, and assistance use in line with targets.

- Process in program implementation covers development/training/assistance, response of program providers, monitoring, and continued development.

- Output in program implementation includes an increase or improvement from prior conditions.

Heryendi's study focused on effectiveness as part of program evaluation; hence, it is not relevant to the study at hand. Effectiveness in this study is closely correlated with the education program targeted by the study. Thus, the arguments presented in Steers (1985), stating the use of several indicators to measure effectiveness, specifically program target accuracy, program dissemination, program objectives, and program monitoring, are more relevant to this study (Steers, 1985). The descriptions of the dimensions presented by Budiani, among others, are listed below.

\subsection{Program Target Accuracy}

Program target accuracy is the extent that program beneficiaries were accurately preplanned. BOSDA's program target accuracy is considered effective as Bekasi Municipal Government, through the Regional Education Office, had determined the target beneficiaries of BOSDA to the appropriate madrasas. As shown in Table 3.1, out of the 214 madrasas available, not all of them received BOSDA funds, whereas nine madrasas did not receive funds in 2018 and eight did not receive funds in 2017. 
Table 3.1. Number of Madrasas Receiving BOSDA Funds

\begin{tabular}{|l|l|l|l|l|l|l|l|l|}
\hline \multirow{2}{*}{ Year } & \multicolumn{4}{|l|}{$\begin{array}{l}\text { Madrasas in Bekasi } \\
\text { Municipality }\end{array}$} & \multicolumn{3}{|l|}{$\begin{array}{l}\text { Madrasas } \\
\text { BOSDA Fund }\end{array}$} \\
\cline { 2 - 9 } & MIS & MIN & $\begin{array}{l}\text { MT } \\
\text { SS }\end{array}$ & $\begin{array}{l}\text { MT } \\
\text { SN }\end{array}$ & MIS & MIN & $\begin{array}{l}\text { MT } \\
\text { SS }\end{array}$ & $\begin{array}{l}\text { MT } \\
\text { SN }\end{array}$ \\
\hline 2018 & 135 & 1 & 75 & 3 & 129 & 1 & 73 & 3 \\
\hline 2017 & 135 & 1 & 75 & 3 & 129 & 1 & 72 & 3 \\
\hline
\end{tabular}

Source: Processed data from Bekasi Municipality's Ministry of Religious Affairs Office and Bekasi Municipal Education Office (2019)

There are two reasons why not all madrasas receive BOSDA funds: (i) the budget ceiling for the Bekasi Municipality Regional Budget is insufficient to fulfill all the submitted proposals or (ii) the madrasas themselves do not make a proposal for funding because they do not meet the required criteria. These criteria are as follows: (a) permission to operate as a private school, (b) not being merged with another school, (c) being accredited, and (d) having at least 20 students. The Coordinator of the SD/MI level BOSDA of Bekasi Municipal Education Office stated that if funds from the Bekasi Municipal Government are insufficient, then Bekasi's Ministry of Religious Affairs Office and Municipal Education Office will select and reexamine which madrasa will receive BOSDA fund. In other words, not all madrasas will receive BOSDA fund; only those considered to be in need for BOSDA funds will be prioritized over those that are already established.

Moreover, MIN Bekasi Municipality and MTsN 1 Bekasi Municipality were in line with the objectives of the BOSDA program, and both madrasas have fulfilled the BOSDA program requirements, especially MIN Bekasi Municipality, which has been adopting the BOSDA program since its implementation in 2012. The same is true for MTsN 1 Bekasi Municipality, which implemented the BOSDA program in 2017 when BOSDA funds for MTsN were first offered. Hence, the target beneficiaries of the BOSDA program are in line with the objectives of the BOSDA program.

\subsection{Program Dissemination}

Program dissemination is the capacity of program organizers to provide information about a program's implementation to the program's beneficiaries. This information is used to generate optimum results and assist in the continuation of a task. Program dissemination within the BOSDA program is conducted to help madrasas understand how they can benefit from the program. Information about program implementation must be conveyed to the madrasas through the program organizer, the Bekasi Municipal Government, by way of the Regional Education Office. Since its implementation in 2012, the Bekasi Municipal Education Office has been conducting program dissemination once every year in the months of February and March. These program dissemination sessions are attended by the heads of the madrasas and are considered of utmost importance because they provide overall information about the BOSDA program, such as the disbursement of funds, allowances and prohibitions of fund use, and a report on current use. The Head of MTsN 1 Bekasi Municipality, Bukhori, stated the following about the sessions: "I think it is important, ya, as a reference, ya, a reference to how its procedures are, its use, and its accountability" (Bukhori, personal communication, May 4, 2019). In line with the Head of MTsN 1 Bekasi Municipality, the Head of MIN Bekasi Municipality also stated the same: "Yes, it is important, so we know the technical guidelines for the use of BOSDA funds because the technical guidelines are changing every year" (Genon, personal communication, April 16, 2019). These sessions gain more significance each year because the technical guidelines for implementing the BOSDA program change every year. Consequently, program dissemination is crucial for discussing the conditions stipulated in these technical guidelines. Accordingly, program dissemination can enhance the overall knowledge of the participants.

\subsection{Program Objective}

Program objective refers to the extent to which a program outcome/result and a predetermined program objective align. According to Duncan, as cited by Steers (1985), achieving objectives is a process. This process must be divided into stages to ensure that the final objective can be achieved. These stages could include sectional achievements or periodical achievements. Achieving objectives comprises two factors: punctuality and concrete target. Thus, the program objective in this case is the process of achieving the program objectives that can be observed through punctuality and achieving concrete target (Steers, 1985). Punctuality in the BOSDA program for madrasas can be observed from the mechanism process, which consists of three stages: (i) proposal submission at the end of the previous year from the madrasas to the Regional Education Office through the Bekasi Municipality Ministry of Religious Affairs Office, which, if subsequently accepted, will allow the madrasa to take part in the dissemination program; (ii) disbursement, collection, and use of BOSDA funds by the head of the madrasa and the treasurer once every six months; and (iii) reporting the use of funds to the Regional Education Office. Furthermore, the objective of the BOSDA program was to help students at public SD/MI and SMP/MTs schools with the school operational expenses and to also provide the madrasas with operational activity assistance to improve the quality of learning. 
The disbursement process experienced delays during the 2017 and 2018 implementation. In fact, in 2018, funds were only disbursed once rather than twice, as originally planned. This inconsistent disbursement of funds had a large impact on the operational activities of madrasas. This effect was reflected in the madrasas' activities and procurement of goods and services for that year. For instance, MIN Bekasi Municipality removed some activities and the procurement of goods for the following semester as a result of not receiving a BOSDA fund. If they had kept these activities and goods, they would have had to have parents pay another Education Implementation Contribution (Sumbangan Penyelenggaraan Pendidikan, SPP) fee. On the other hand, MTsN 1 Bekasi Municipality made up for the lost BOSDA fund by having the parents pay another SPP fee. They took this measure because they had a large number of students (1,225 in total) in 2018 and required a substantial budget to meet their needs. Even though since the BOSDA fund in 2017 at MTsN 1 Bekasi Municipality have not collected SPP fees. This is because the two madrasas only have two sources of funds: BOS Pusat and BOSDA. As a result of the delay in implementing the BOSDA program in 2017 and 2018, the objective of the BOSDA program was not achieved.

\subsection{Program Monitoring}

Program monitoring refers to activities that are carried out after program implementation. These activities focus on the program beneficiaries to see whether the planned objectives have been achieved. This activity is called monitoring. Moreover, according to Situmorang and Jubir (1994), there are two monitoring techniques: internal monitoring and external monitoring. Internal monitoring is conducted by an officer within the organization itself, whereas external monitoring is conducted by an officer from outside the organization. Both types of monitoring must be carried out to assess whether the implementation of the program is in accordance with the predetermined plan. The internal monitoring for this program is codified in the Technical Guidance under 420/Kep.118-Dikdas/II/2018 in Chapter 9 on monitoring and evaluation. It states that the school headmaster is required to conduct internal evaluations with the school committee. In its implementation, the two madrasas, namely, MIN Bekasi Municipality and MTsN 1 Bekasi Municipality, did not conduct internal evaluations with their school committee. In an in-depth interview with Halimah, the Treasurer of MIN Bekasi Municipality, she stated the following: "We have, Miss, monitoring like that we do it every year we make a letter of accountability. Well, there it's verified as well, is it in line or not" (Halimah, personal communication, April 12, 2019). Similarly, the Treasurer of MTsN 1 Bekasi Municipality said the following: "Yes, we conduct internal monitoring when we make the letter of accountability, we conduct monitoring and auditing at once like that" (Siti Salimah, personal communication, April 15, 2019). According to the interviews, leaders of madrasas did not understand that internal evaluations should be conducted before writing a letter of accountability. They thought that writing a letter of accountability is in itself the monitoring activity.

External monitoring is conducted by Bekasi Municipal Education Office through indirect (written) monitoring with the submission of a letter of accountability (Surat Pertanggung Jawaban, SPJ). This letter contains a report on the management and use of the BOSDA funds to the Education Office at every disbursement through the Finance Sub-Section of the Education Office. Another party that conducts monitoring is the Bekasi Municipal Inspectorate; they perform direct monitoring or direct inspection. However, they do not perform that inspection every year, and it is unknown when they will be renewing their monitoring. External monitoring in the form of direct inspection helps to ensure that the use of BOSDA funds in the field is in line with the report made, and it can prevent irregularities in the use of BOSDA funds that is not in line with the technical guidance.

\section{CONCLUSION}

On the basis of all the preceding analysis, we can conclude that the BOSDA program is fairly effective. This conclusion is based on analyses of the respective dimensions described in the previous passages. They indicate that out of the four dimensions, two met the required conditions and two did not. The dimensions that met the required conditions were program target accuracy and program dissemination, whereas the dimensions that did not were program objective and program monitoring.

Madrasas help achieve comprehensive education equality in local governments and, hence, nationwide. As BOSDA plays a substantial role in the development of madrasas, the central government, in this case the Ministry of Religious Affairs, should collaborate with the local government to ensure that madrasas receive the support they need to grow.

\section{REFERENCES}

[1] A. Fadjar, Madrasah dan Tantangan Modernitas, Bandung: Mizan, 1998

[2] F. Alawiyah, "Pendidikan Madrasah Di Indonesia," Aspirasi, vol. 5, no. 1, pp. 52-66, 2014.

[3] A. Murtadho, "Memperkokoh Kualitas 
Pendidikan Madrasah Berbasis Manajemen Mutu Terpadu (TQM)," Forum Tarbiyah, vol. 10, pp. 91-114, 2012.

[4] E. Hidayat, "Faktor-Faktor Yang Mempengaruhi Mutu Sekolah (Pengantar Faktor Kinerja Mengajar Guru Dan Pemanfaatan Sumber Belajar," Jurnal Administrasi Pendidikan, vol. 21, no. 1, pp. 18, 2014.

[5] J. Cresswell, Qualitative Inquiry And Research Design: Choosing Among Five Approach, London: Sage Publication, 2014.

[6] U. Silalahi, Metode Penelitian Sosial Kuanttatif, Bandung: PT Refika Aditama, 2015.

[7] A. Subagyo, Efektivitas Program Penanggulangan Kemiskinan Dalam Pemberdayaan Pedesaan Yogyakarta, Yogyakarta: Universitas Gadjah Mada Press, 2000.

[8] T. Gie, Ensiklopedia Administrasi, Jakarta: Gunung Agung, 1997.
[9] R. Dale, Evaluaring Development Program And Project, New Delhi: Sage, 2004.

[10] N. W. Budiani, "EFektivitas Program Penanggulangan Pengangguran Karang Taruna "Eka Taruna Bhakti" Desa Sumerta Kelod Kecamatan Denpasar Timur Kota Denpasar," Ekonomi dan Sosial, vol. 2, pp. 49-57, 2007.

[11] R. M. Steers, Efektivitas Organisasi, Jakarta: Ppm. Erlangga, 1985.

[12] Viktor, M. Situmorang and Jusuf Juhir, Aspek Hukum Pengawasan Melekat, Yogyakarta: Rineka Cipta, 1994

[13] Syubhan Annur Mustika Wati, Sayidah Mahtari, Miranti DIah Prantika, "Suitanable Development Goals (SDGs) dan Peningkatan Kualitas Pendidikan," in Seminar Nasional Pendidikan, Banjarmasin, 2018 